\title{
Urine Interleukin-1 $\beta$ Can Be Used for Early Prediction of Urinary Tract Infection in Children
}

\section{idrar Interlökin-16 Düzeyi Çocuklarda idrar Yolu Enfeksiyonun Erken Belirteci Olarak Kullanılabilir}

\section{Asuman Gedikbaşı ${ }^{1}$ (D), Esra Şevketoğlu² (D), Savaş Karyağar ${ }^{3}$ (D), Sevda Sağlampınar Karyağar ${ }^{2}$ (D), Sadık Sami Hatipoğlu² ${ }^{\mathbb{D}}$, Alev Yılmaz ${ }^{4}$ (])}

\author{
${ }^{1}$ Istanbul University, Institute of Child Health, Department of Pediatric Basic Sciences, Istanbul, Turkey \\ ${ }^{2}$ University of Health Sciences, Bakırköy Dr. Sadi Konuk Training and Research Hospital, Department of Pediatrics, Division of Pediatric Intensive Care, \\ Istanbul, Turkey \\ ${ }^{3}$ Okmeydanı Training and Research Hospital, Department of Nuclear Medicine, Istanbul, Turkey \\ ${ }^{4}$ Istanbul University, Istanbul Faculty of Medicine, Department of Pediatrics, Division of Pediatric Nephrology, Istanbul, Turkey
}

ORCID ID: A.G. 0000-0001-712I-6077; E.Ş. 0000-0002-8330-2877; S.K. 0000-0002-3259-9666; S.S.K. 0000-0002-6356-8280; S.S.H. 0000-0001-8865-4049; A.Y. 0000-0003-1743-1491

Citation/Attf: Gedikbaşı A, Şevketoğlu E, Karyağar S, Sağlampınar Karyağar S, Hatipoğlu SS, Yılmaz A. Urine interleukin-1 $1 \beta$ can be used for early prediction of urinary tract infection in children. Çocuk Dergisi - Journal of Child 2020;20(1):1-6. https://doi.org/10.26650/jchild.2020.1.0001

ABSTRACT

Objective: Interleukin 1 beta (IL-1B) is an essential proinflammatory mediator emerging early in bacterial infection. Urinary tract infections (UTI) are one of the most common bacterial infections during childhood. This prospective study aimed to explore whether urine levels of IL-1 $\beta$ could be used as a biomarker of UTI. The study also aimed to define the optimal cut-off level for urine IL-1 $\beta$ to detect UTI in children.

Material and Method: Sixty patients with symptomatic UTI and 29 healthy controls were registered in the study. After taking informed consent, urine culture, urinalysis, serum urea and creatinine, C-reactive protein (CRP) and serum white blood cell count measurements were performed in both groups. Urine IL-1 $\beta$ was analyzed by enzyme-linked immunosorbent assay. Results: The mean urine IL-1 $\beta$ level was significantly greater in the UTI group than in the controls $(21.14 \mathrm{pg} / \mathrm{ml}$ vs $2.60 \mathrm{pg} / \mathrm{ml}, \mathrm{p}=0.0001)$, and using a cut-off of $6.11 \mathrm{pg} / \mathrm{ml}$ for urine IL-1 $\beta$ for early prediction of UTI, sensitivity and specificity were $100 \%$ and $93.1 \%$, respectively (AUC: 0.971). The mean urine IL-1 $\beta /$ creatinine ratio (ulL-1 $\beta / \mathrm{Cr}$ ) was also significantly greater in the UTI group $(46.87 \mathrm{pg} / \mathrm{mgCr}$ vs $3.29 \mathrm{pg} / \mathrm{mgCr}$; $\mathrm{p}=0.0001$ ), and using a cut-off of $9.45 \mathrm{pg} / \mathrm{mgCr}$ for ulL-1 $\beta / \mathrm{Cr}$ for early prediction of UTI, sensitivity, and specificity were $96.7 \%$ and $89.7 \%$, respectively (AUC: 0.963).

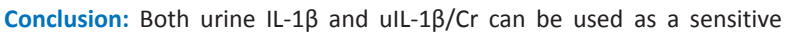
biomarker for early prediction of UTI. Further research with larger groups is necessary to support our results.

Keywords: Interleukin 1 beta (IL-1ß), urinary tract infections (UTI), biomarker öz

Amaç: Interlökin 1 beta (IL-1 $\beta$ ) bakteriyel enfeksiyon sırasında erken görülen önemli bir proinflamatuar mediatördür. İdrar yolu enfeksiyonları (IYE), çocuklarda görülen en yaygın bakteriyel enfeksiyonlardan biridir. Bu prospektif çalışmanın amacı, idrar IL-1 $\beta$ seviyelerinin IYE' nin güvenilir bir belirleyicisi olarak kullanılıp kullanılamayacağını araştırmak ve çocuklarda IYE'nin erken teşhisinde, idrar IL-1 $\beta$ için optimum kestirim seviyesini belirlemektir.

Gereç ve Yöntem: Semptomatik iYE olan 60 hasta ve 29 sağlıklı kontrol çalışmaya dahil edildi. Bilgilendirilmiş onam alındıktan sonra her iki grupta idrar kültürü, idrar tahlili, serum üre ve kreatinin, C-reaktif protein (CRP) ve serum beyaz küre sayımı analizleri yapıldı. İdrar IL-1 $\beta$, enzim bağlı immünosorbent (ELISA) analizi ile ölçüldü. IYE hastalarında, dimerkaptosüksinik asit (DMSA) radyonüklid taraması yapıldı.

Bulgular: Ortalama idrar IL-1 $\beta$ seviyesi iYE grubunda kontrol grubundan anlamlı derecede yüksekti $(21,14 \mathrm{pg} / \mathrm{ml}$ 'ye karşı $2,60 \mathrm{pg} / \mathrm{ml}, \mathrm{p}=0,0001)$ ve idrar IL-1 i için 6,11 pg/ml'lik bir kestrim kullanılarak iYE'nin erken tanısında duyarlılık ve özgüllük sırasıyla $\% 100$ ve $\% 93,1$ idi (AUC:0,971). Ortalama idrar IL-1 $\beta /$ kreatinin oranı (uIL-1 $\beta / \mathrm{Cr}$ ) de IYE grubunda anlamlı şekilde daha yüksekti $(46,87 \mathrm{pg} / \mathrm{mgCr}-3,29 \mathrm{pg} / \mathrm{mgCr} ; \mathrm{p}=0,0001)$ ve ulL$1 \beta / \mathrm{Cr}$ için mgCr için 9,45 pg/mg kestirim kullanılarak, IYE'nin erken tanısında, duyarlılık ve özgüllük sırasıyla \%96,7 ve \%89,7 idi (AUC: 0,963). Sonuç: Hem idrar IL-1 $\beta$ hem de ulL-1 $\beta / C r$, iYE'nin erken tanısı için hassas bir belirteç olarak kullanılabilir. Sonuçlarımızı doğrulamak için daha büyük hasta grupları ile daha fazla araştırma yapılması gerekmektedir.

Anahtar Kelimeler: Interlökin1 beta (IL-1ß), idrar yolu enfeksiyonları (IYE), biyobelirteç

Corresponding Author/Sorumlu Yazar: Asuman Gedikbaşı E-mail: asuman.gedikbasi@istanbul.edu.tr

Submitted/Başvuru: 08.04.2019 • Revision Requested/Revizyon Talebi: 05.07.2019 • Last Revision Received/Son Revizyon: 22.07.2019 •

Accepted/Kabul: 25.07.2019 


\section{INTRODUCTION}

Urinary tract infections (UTI) are one of the most frequent types of childhood infections diagnosed by pediatric clinicians. A missed diagnosis may lead to long-term medical difficulties, including hypertension and renal scarring with reduced renal function $(1,2)$. Routine clinical practice in Turkey in cases with pyuria uses positive nitrite tests in urinalysis to detect UTI and to choose which treatment to start with. Unfortunately, empiric routine antibiotic treatment is related to antibiotic resistance. The detection of bacteria in urine cultures is the gold standard for the diagnosis of UTI in children (3). However, standard plate count procedures in urine culture may be expensive, time-consuming, inefficient, and maybe even incorrect due to the unsuitable handling of samplings. Urine samples are left for extended periods before analysis, which is often the reason for incorrect results. It is important to explore more sensitive, safer and more rapid indicators for a more precise diagnosis of UTI, as this would be of great value for decision making for the treatment of children with suspected UTI, while waiting for the urine culture results.

Cytokines are minor soluble peptides playing an important role in mediating the inflammatory response to numerous infectious and inflammatory processes (4). Most noteworthy are uropathogenic bacteria which stimulate epithelial cells in the interstitial tissue, glomerular endothelial cells, and macrophages to produce proinflammatory cytokines (5). IL-1 is the first cytokine seen in the antigen recognition immune cascade and occurs in two main forms: IL-1 $\alpha$ and IL-1 $\beta$. Although all nucleated cells can secrete IL- $1 \alpha$ and IL-1 $\beta$ after a stimulus, activated mononuclear phagocytes are the main cellular sources of IL-1 (6). IL-1 $\alpha$ is principally a membrane- and cell-associated cytokine, whereas IL-1 $\beta$ is presently free in biological fluids, those containing serum, and urine and synovial fluids (7). The main biological distinction between the two forms has made IL-1 $\beta$ the more functional choice for study in human urine. IL-1 $\beta$ has also been known to be a fever-producing endogenous pyrogen that is detected early and throughout the inflammatory progression, which is also responsible for acute-phase reactions, as well as fever development (8). Here, we present the continuance of our other project in which we are investigating a cost-effective biomarker for rapid and accurate diagnosis of urinary tract infections (9). IL-1 $\beta$ was preferred for research in this prospective study because it appears in an early stage during the immune response cascade. The evaluation of IL-1 $\beta$ in urine specimen is both clinically workable and potentially beneficial in UTI, especially because of its role in systemic inflammation.

The purpose of this prospective study was to explore whether a urine level of IL-1 $\beta$ could be used as a reliable indicator of UTI and to define the ideal cut-off level for urine IL-1 $\beta$ in identifying UTI in childhood.

\section{MATERIAL AND METHODS}

This multicenter prospective study was conducted over a one year period at three different research and training hospitals in Turkey. Sixty patients who applied to the related outpatient clinics with symptomatic UTI (patient group) and 29 healthy children (control group) were involved in this study. After obtaining informed consent, blood and urine samples were taken to analyze C-reactive protein (CRP), serum urea, creatinine, white blood cell count, urine creatinine, urinalysis and urine culture from all children. Serum CRP was measured via nephelometry (Dade Behring Marburg GmbH, Marburg, Germany), and serum urea, creatinine, and urine creatinine were evaluated using an enzymatic colorimetric method (Abbott Architect ci16200, USA). Furthermore, white blood cell count measurements were performed with a hematology analyzer (LH 780, Beckman Coulter, USA). Leukocytosis was defined as a leukocyte amount greater than the normal value, according to age, and positive CRP was described as a CRP level greater than $5 \mathrm{mg} / \mathrm{L}$. Urinalysis, including dipstick and automated microscopic examination of urine with the IQ 200 IRIS full automatic urine analyzer, was measured.

Urine specimens for culture, urinalysis and IL-1 $1 \beta$ were obtained by accumulating bag or midstream urine in the control group; whereas, in symptomatic patients, urine samples were obtained via a catheter. Urine specimens were carried from point-oforigin to the laboratory to be analyzed without any loss of time. UTI was diagnosed in case of significant bacteriuria $(\geq 10.000$ $\mathrm{CFU} / \mathrm{ml}$ ) in the urine culture (2). Children of the control group were excluded from the study if they had bacterial growth in their urine. After inoculation, urine samples were centrifuged at $4^{\circ} \mathrm{C}$ for 15 minutes at $13.000 \times$ g. Afterwards, aliquots of urine supernatant were stored at $-80^{\circ} \mathrm{C}$ for assaying. The IL-1 $\beta$ quantity in the urine was determined using RayBio ${ }^{\circledR}$ Human IL-1 $\beta$ ELISA KIT (Cat no: ELH-IL1 beta-001), obtained from RayBiotech, Inc. (Norcross, GA), following the manufacturer's instructions. The RayBio Human IL-1 $\beta$ ELISA (Enzyme-Linked Immunosorbent Assay) kit is an invitro evaluation for quantitative measurement of human IL-1 $\beta$ in the urine. This assay services an antibody specific to human IL-1 $\beta$ coated on a well plate. Standards and samples were pipetted into the wells and, in cases with IL-1 $\beta$ present in the sample, these were bound to the wells by the immobilized antibody. The wells were washed and biotinylated anti-human IL-1 $\beta$ was added. After washing away all unbound substances, HRP-conjugated streptavidin was pipetted to the wells. The wells were again washed, and a TMB (tetramethylbenzidine) substrate solution was inserted to the wells. The reaction was terminated by adding stop solution and/ or absorbance of the resulting yellow product measured at 450 $\mathrm{nm}$. The absorbance was comparative to the concentration of IL$1 \beta$. A standard curve was created by plotting absorbance values versus IL-1 $\beta$ concentrations of calibrators and concentrations of unknown specimens were ascertained using this standard curve. Related IL-1 $\beta$ levels were expressed in $\mathrm{pg} / \mathrm{ml}$.

The whole population in the study group were investigated with a dimercaptosuccinic acid (DMSA) scan. The DMSA evaluation was performed within 7 days to differentiate acute pyelonephritis from cystitis. Patients with normal scintigraphy were accepted as lower UTI. When scintigraphy exposed renal parenchymal lesions, second scintigraphy was performed at least 6 months later to assess the evolution of renal lesions. 
On the follow-up examination, we presumed any persistent lesions as scars, in the absence of UTI. Diagnosis of acute pyelonephritis was established only in cases with a totally or partially reversible lesion on the DMSA evaluation. This study was approved by Bakirkoy Maternity and Childrens Hospital ethics committee (07/02/2008 no:126) and was performed according to the ethical standards of the Declaration of Helsinki.

Statistical calculations were performed with the NCSS 2007 program for Windows. In addition to standard descriptive statistical calculations (mean, standard deviation, median and geometric mean), the Kruskal Wallis test was performed for the comparison of groups, the post hoc Dunn's multiple comparison test was applied in the comparison of subgroups, the Mann Whitney $U$ test was used in the comparison of two groups, and the Chi-square test was performed for the evaluation of qualitative data. The results were evaluated within a $95 \%$ confidence interval. The ratio of IL-1 $\beta$ and IL-1 $\beta / C r$ were tested for their normal distribution. Logarithmic transformations were applied as needed in order to achieve a distribution of normal. We used geometric mean IL- $1 \beta$ and IL- $1 \beta / C r$ ratios. Receiver operating curve $(\mathrm{ROC})$ analysis was performed to determine the sensitivity and specificity of different cut-off points for IL-1 $\beta$ and IL-1 $/ \mathrm{Cr}$ in the prediction of UTI. The most appropriate cut-off point was chosen according to ROC analysis and the area under the curve (AUC) was calculated. A statistical significance level was established at $p<0.05$.

\section{RESULTS}

The UTI group involved 60 children ( 52 female, 8 male) with a mean age of $5.95 \pm 3.84$ years ( 2 months -12 years). The control group consisted of 29 healthy cases ( 13 female, 16 male) with a mean age of $6.67 \pm 4.52$ years ( 3 months- 14 years). Serum urea and creatinine levels were within normal limits for all children, in both the UTI and control groups.

The mean ulL-1 $\beta$ level was significantly higher in the UTI group than in the controls $(21.14 \mathrm{pg} / \mathrm{ml}$ vs $2.60 \mathrm{pg} / \mathrm{ml}, \mathrm{p}=0.0001)$
(Table 1, Figure 1A). ROC analysis found an optimal cut-off level of $6.11 \mathrm{pg} / \mathrm{ml}$ for ulL-1 $\beta$ for the prediction of UTI. Using this level of $6.11 \mathrm{pg} / \mathrm{ml}$ of ulL-1 $\beta$ for the diagnosis of UTI, sensitivity, and specificity were found $100 \%$ and $93.1 \%$, respectively (Figure 2A). Besides, the positive and negative predictive values of this cut-off point were $96.8 \%$ and $100 \%$, respectively. For cases with ulL-1 $\beta$ higher than this cut-off value, the possibility of UTI increased 14 times (positive likelihood ratio: 14.5, and negative likelihood ratio: 0.00 ).

We also found a significantly higher mean ulL-1 $\beta / \mathrm{Cr}$ ratio in the UTI group in contrast to the control group $(46.87 \mathrm{pg} / \mathrm{mgCr}$ vs $3.29 \mathrm{pg} / \mathrm{mgCr}$; $\mathrm{p}=0.0001$ ) (Table 1 Figure $1 \mathrm{~B}$ ). Using a cutoff of $9.45 \mathrm{ng} / \mathrm{mgCr}$ for $\mathrm{uNGAL} / \mathrm{Cr}$ ratio for the diagnosis of UTI, sensitivity, and specificity were found $96.7 \%$ and $89.7 \%$, respectively (Figure $2 \mathrm{~B}$ ). Furthermore, positive and negative predictive values were $95.1 \%$ and $92.9 \%$, respectively. When ulL- $1 \beta / C$ ratio was higher than this cut-off value, the possibility of UTI increased 9 times (positive likelihood ratio: 9.34, and negative likelihood ratio: 0.04). AUC result was 0.971 percent of the time for ulL-1 $\beta$ and 0.963 percent of the time for ulL-1 $\beta$ $/ \mathrm{Cr}$ ratio, suggesting that both uIL-1 $\beta$ and UIL-1 $/ \mathrm{Cr}$ ratios were excellent markers for the diagnosis of UTI in children.

Urine uIL-1 $\beta$ and uIL-1 $\beta / C$ r ratios were not correlated with serum CRP, serum CRP, urine nitrite test, pyuria, urine $\mathrm{pH}$ and specific gravity $(p>0.05)$. Furthermore, urine IL-1 $\beta$ was not associated with leukocytosis in serum and leukocyte esterase reaction in the urine. However, the $u I L-1 \beta / C r$ ratio was significantly higher in the patients with $2(+)$ and $3(+)$ leukocyte esterase reaction in the urine specimen and the patients with leukocytosis in serum $(p<0.05)$.

Of sixteen out of 60 patients in the UTI group, parenchymal lesions were found in the first DMSA scan. The following second scintigraphy discovered that 12 of them had persistent renal damage and 4 of them had acute pyelonephritis at the time of admission. The mean ulL-1 $\beta$ was higher in these patients with

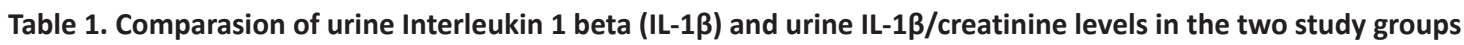

\begin{tabular}{|c|c|c|c|c|c|}
\hline Study groups urinalysis & & $\begin{array}{c}\text { Urine IL-1ß } \\
(\mathrm{pg} / \mathrm{ml})\end{array}$ & $p$ & $\begin{array}{l}\text { Urine IL-1 } 1 \beta / \mathrm{cr} \\
(\mathrm{pg} / \mathrm{mg})\end{array}$ & $\mathbf{p}$ \\
\hline Control group $(n=29$ ) & & 2.60 & $0.0001^{*}$ & 3.29 & $0.0001^{*}$ \\
\hline UTI group $(n=60)$ & & 21.14 & & 46.87 & \\
\hline \multirow[t]{8}{*}{ UTI group } & Leukocytosis (-) n:27 & 19.20 & 0.234 & 28.08 & $0.001 *$ \\
\hline & Leukocytosis (+) n:30 & 23.01 & & 70.90 & \\
\hline & CRP $<5 n: 33$ & 18.97 & 0.064 & 35.28 & 0.077 \\
\hline & $C R P>5 n: 22$ & 24.46 & & 62.38 & \\
\hline & leukocyte esterase (-) & 15.75 & 0.311 & 19.36 & $0.007^{*}$ \\
\hline & leukocyte esterase (+) & 22.58 & & 56.83 & \\
\hline & DMSA (-), n:44 & 20.91 & 0.936 & 50.61 & 0.058 \\
\hline & DMSA (scar), n:12 & 19.37 & & 27.84 & \\
\hline
\end{tabular}


A

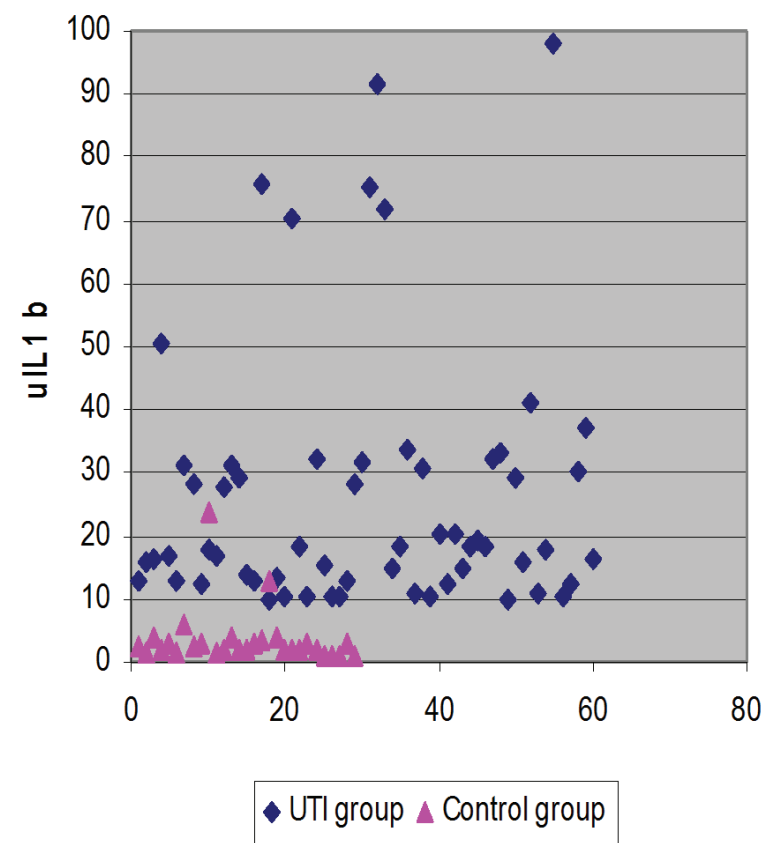

B

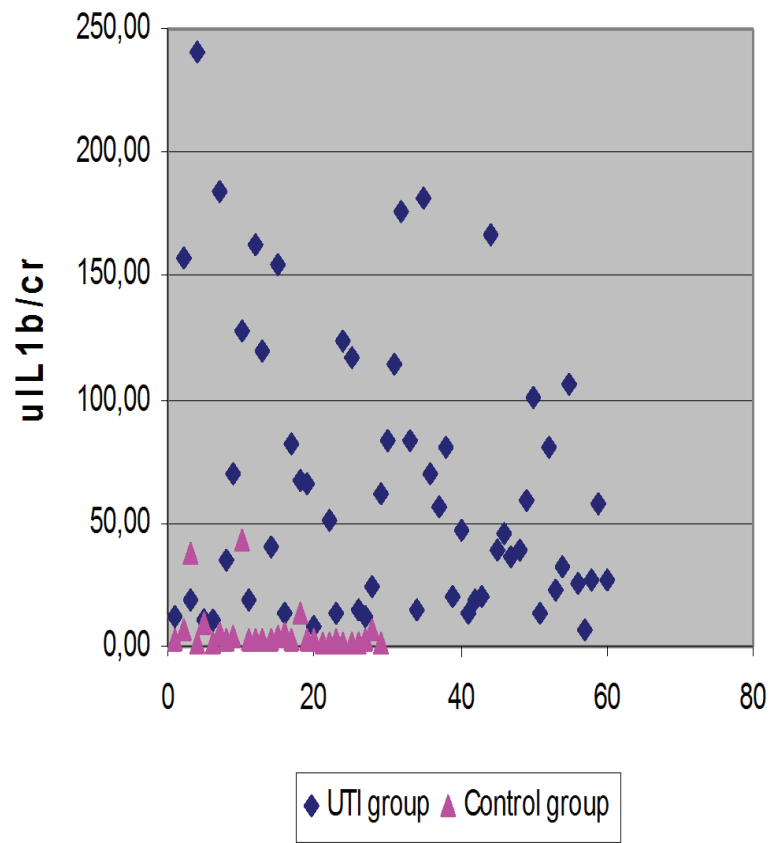

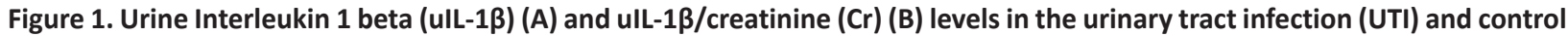
group, respectively.

A

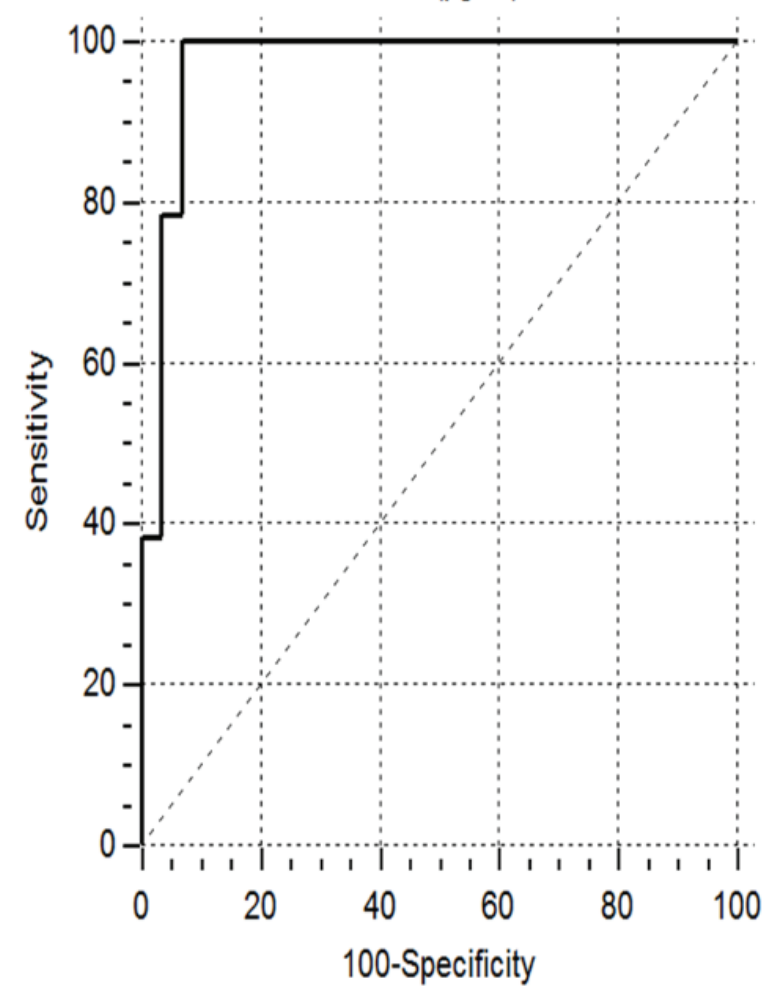

B

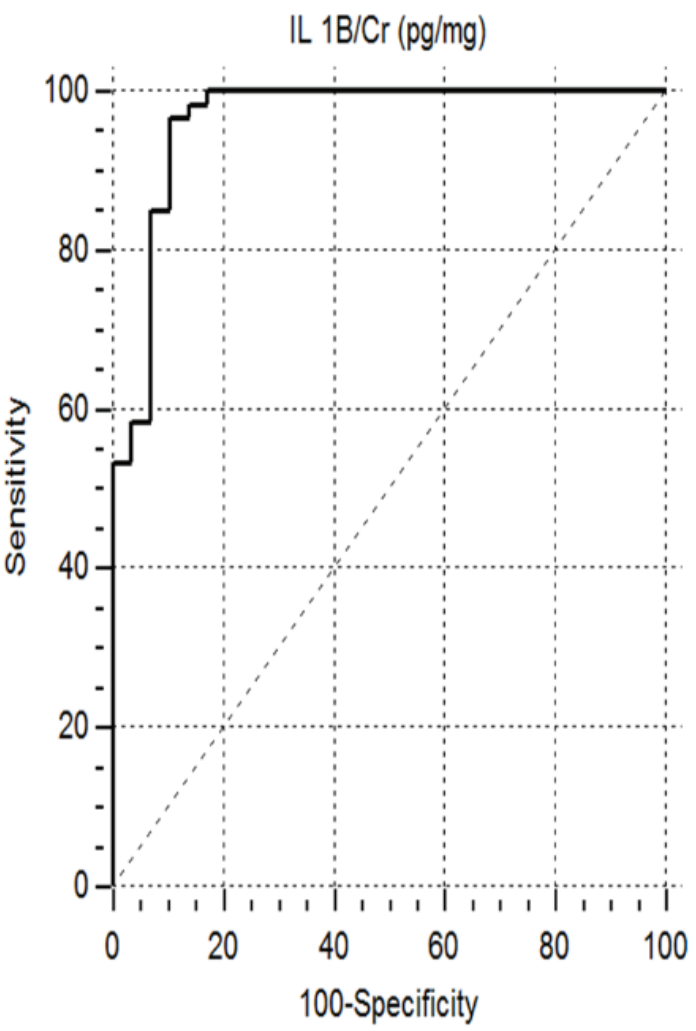

Figure 2. Receiver operating curve for uIL-1 $\beta$ (A) and urinary IL-1 $1 \beta /$ creatinine (B). (A) Area under the curve $(A U C)=0.971$ for ulL-1 $\beta$ (A), AUC=0.963 for IL-1 $\beta / \mathrm{cr}$ (B). 
renal scars than in the patients with normal DMSA scan findings $(p<0.05)$ (Table 1). However, the mean ulL-1 $\beta / C r$ ratio was not different in those two groups ( $p>0.05$ ) (Table 1). Due to the limited number of subjects, ROC analysis was not appropriate to be performed on patients with acute pyelonephritis and renal scars.

\section{DISCUSSION}

Interleukin-1 (IL-1) is a principally macrophage-produced interleukin, which mediates the host's inflammatory response in characteristic immunity. Two main forms exist, designated as $\alpha$ and $\beta$, with apparently identical biological activity in each. Both forms are stable tetrahedral globular proteins and are administered at the cell membrane or extracellularly to produce the mature molecule. Most of the IL-1 activity in plasma is from IL-1 $\beta$, which is found free in biological fluids (10). IL-1 $\alpha$ is not regularly found in circulation or in body fluids, except in case of severe disease, in which circumstances the cytokine may be released from dying cells or by proteolysis after calpain-mediated cleavage. However, in cells of monocytic lineage, pro-IL-1 $\beta$ cleavage takes place and mature IL-1 $\beta$ is secreted from stimulated cells (11). In a UTI, both immune cells and numerous other cell types (such as endothelial and uroepithelial cells) take part in the host response. In a study evaluating urinary cytokine response about bacteriuria in an adult population, Nils Rodhe et al. found meaningfully higher levels of urine CXCL1, CXCL8, and IL-6 in subjects with asymptomatic bacteriuria in contrast to negative controls, and even higher levels in acute cystitis (12). An earlier report has shown that human proximal tubular epithelial cells can produce IL-1 $\alpha$, IL-1 $\beta$ at the protein level, with subsequent stimulation with a heat-inactivated pyelonephritogenic Escherichia coli strain DS-17 (13). In another animal study, it was confirmed that intrinsic renal cells constitutively express IL- $1 \beta$ and that they are the main source of the improved IL-1 $\beta$ production that is seen during anti-GBM glomerulonephritis in rats (14).

Gurgoze et al. compared serum proinflammatory cytokines (IL-1 $\beta$, IL-6, and TNF-a) levels in 34 patients with acute pyelonephritis, of whom 42 patients with lower UTI demonstrated increased serum IL-1 $\beta$ levels, which were more obvious in acute pyelonephritis than in lower UTI (15). In our study, we preferred urine samples because obtaining them is easy and painless for the children. The finding of cytokines in urine has been used in the diagnosis and monitoring of acute pyelonephritis (16-18). However, there are relatively few studies of the role of urine IL-1 in children with lower UTI. JINan Sheu et al. suggested that urine IL-1 $\beta$ levels may serve as a valuable marker in the early detection of acute pyelonephritis in febrile children (19). In our study, we evaluated a larger group of children with lower UTI (56 acute cystitis, 4 acute pyelonephritis and 29 healthy controls) and found that $9.45 \mathrm{pg} /$ mg for ulL-1 $\beta /$ creatinine can be used to predict lower UTI for children. The cut-off level of $9.45 \mathrm{pg} / \mathrm{mg}$ for early prediction of UTI showed a related sensitivity and specificity of $96.7 \%$ and $89.7 \%$, respectively. The positive and negative predictive values were $95.1 \%$ and $92.9 \%$, respectively.
Although in our daily practice, the first urinary test performed is often a dipstick test with measurement of leukocyte esterase and nitrite, there is still a high false-positive and/ or false-negative rate based on related laboratory findings (20). Leukocyte esterase reaction is founded on the release of leukocyte esterase from lysed neutrophils. This test alone to detect pyuria would result in a large number of false-positive and some false-negative results. The nitrite test is based on bacteria that have enzyme nitrate reductase, converting nitrates to nitrites in the urine. Furthermore, if the related bacteria in urine does not produce nitrites, false-negative results are found (21). Earlier resources in the literature have shown that positive leukocyte esterase reactions and nitrite tests are not reliable indicators of UTI (22). In our study, uIL-1 $\beta$ and UIL-1 $\beta / C$ ratios were not correlated to positive serum CRP, positive urine nitrite tests, pyuria, urine $\mathrm{pH}$ or specific gravity $(p>0.05)$. Urine IL-1 $\beta$ was neither related with leukocytosis in serum, nor to a leukocyte esterase reaction in urine, whereas a ulL-1 $\beta / C r$ ratio was significantly higher in the patients with $2(+)$ and $3(+)$ leukocyte esterase reactions in the urine and the patients with leukocytosis in serum $(p<0.05)$. This study suggests the combination of leukocyte esterase and IL-1 $\beta$ in a dipstick with early detection of UTI. However, our results and outcome need to be confirmed, preferably with larger prospective studies with UTI evaluating the use of urinary IL$1 \beta$ in the diagnostic process.

Acknowledgement: We thank to biostatician A. Rana Konyalioglu for statistical calculations, and for support for the study design at the beginning and throughout the study.

Ethics Committee Approval: Ethics committee approval was received for this study.

Informed Consent: Written consent was obtained from the participants.

Peer Review: Externally peer-reviewed.

Author Contributions: Conception/Design of Study- A.G., A.Y., E.Ş.; Data Acquisition- A.G., A.Y., E.Ş., S.K.; Data Analysis/InterpretationA.G., A.Y., E.Ş., S.K., S.S.K., S.S.H.; Drafting Manuscript- A.G., A.Y., E.Ş.; Critical Revision of Manuscript- A.G., A.Y., E.Ş., S.K., S.S.K., S.S.H.; Final Approval and Accountability- A.Y., E.Ş., S.K., S.S.K., S.S.H., A.G.; Technical or Material Support- A.Y., E.Ş., S.K.; Supervision- S.S.H., A.G.

Conflict of Interest: Authors declared no conflict of interest.

Financial Disclosure: Authors declared no financial support.

Teşekkür: Biyoistatist A. Rana Konyalıoğlu'na tasarım ve çalışma süresince istatistiksel hesaplamalar ve çalışmaya desteğinden ötürü teşekkür ederiz.

Etik Komite Onayı: Bu çalışma için etik komite onayı alınmıştır.

Bilgilendirilmiş Onam: Katılımcılardan bilgilendirilmiş onam alınmıştır. 
Hakem Değerlendirmesi: Dış bağımsız.

Yazar Katkıları: Çalışma Konsepti/Tasarım- A.G., A.Y., E.Ş.; Veri ToplamaA.G., A.Y., E.Ş., S.K.; Veri Analizi/Yorumlama- A.G., A.Y., E.Ş., S.K., S.S.K., S.S.H.; Yazı Taslağı- A.G., A.Y., E.Ş.; İçeriğin Eleştirel İncelemesi- A.G., A.Y., E.Ş., S.K., S.S.K., S.S.H.; Son Onay ve Sorumluluk- A.Y., E.Ş., S.K., S.S.K., S.S.H., A.G.; Malzeme ve Teknik Destek- A.Y., E.Ş., S.K.; SüpervizyonS.S.H., A.G.

Çıkar Çatışması: Yazarlar çıkar çatışması beyan etmemişlerdir.

Finansal Destek: Yazarlar finansal destek beyan etmemişlerdir.

\section{REFERENCES/KAYNAKLAR}

1. Joan $L R$, Jane $C F$, Mia EL, Robert B. Urinary tract infection in infants and children: Diagnosis and management. Paediatr Child Health 2014;19(6):315-9.

2. Anacleto, Francisco E, Resontoc, Lourdes P, Grace H. Bedside diagnosis of outpatient childhood urinary tract infection using a three-media dipslide culture test. Pediatr Nephrol 2009;24(8)153943.

3. Jeng DT, Chun $\mathrm{CL}$, Stephan S. Diagnosis of pediatric urinary tract infections. Urol Sci 2016;27(3): 131-4.

4. Guillermo AD, Albert D. Macrophage cytokines: Involvement in immunity and infectious diseases. Front Immunol 2014;5:491.

5. Martin FK, Lars E. Epithelial cells as sensors for microbial infection. J Clin Invest 1997;100(1):6-10.

6. Cecilia G, Charles AD, Alberto M. The interleukin-1 family: back to the future. Immunity 2013;39(6):1003-18.

7. Sheu JN, Chen MC, Cheng SL, Lee IC, Chen SM, Tsay GJ. Urine interleukin-1beta in children with acute pyelonephritis and renal scarring. Nephrol (Carlton) 2007;12(5):487-93.

8. Jean LC, Laurent A, Lluis Quintana-Murci. Human TLRs and IL-1Rs in host defense: Natural insights from evolutionary, epidemiological, and clinical genetics. Annu Rev Immunol 2011;447-91.

9. Yilmaz A, Sevketoglu E, Gedikbasi A, Karyagar S, Kiyak A, Mulazimoglu $M$, et al. Early prediction of urinary tract infection with urinary neutrophil gelatinase associated lipocalin. Pediatr Nephrol 2009;24(12);2387.

10. Charles AD. Interleukin-1 in the pathogenesis and treatment of inflammatory diseases. Blood 2011;117(14):3720-32.
11. Charles AD. Biologic basis for interleukin-I in disease. Blood 1996;87(6):2095-2147.

12. Rodhe N, Löfgren S, Strindhall J, Matussek A, Mölstad S. Cytokines in urine in elderly subjects with acute cystitis and asymptomatic bacteriuria. Scand J Prim Health Care 2009;27(2):74-9.

13. Brauner A, Söderhäll $M$, Jacobson $S H$, Lundahl J, Andersson $U$, Andersson J. Escherichia coli-induced expression of IL-1 $\alpha$, IL-1 $\beta$, IL-6 and IL-8 in normal human renal tubular epithelial cells. Clin Exp Immunol 2001;124(3):423-8.

14. Tesch GH, Yang N, Yu H, Lan HY, Foti R, Chadban SJ, Atkins RC. Intrinsic renal cells are the major source of interleukin-1 beta synthesis in normal and diseased rat kidney. Nephrol Dial Transplant 1997;12(6):1109-15.

15. Gürgöze MK, Akarsu S, Yılmaz E, Godekmerdan A. Proinflammatory cytokines and procalcitonin in children with acute pyelonephritis. Pediatr Nephrol 2005;20(10):1445-8.

16. Horcajada JP, Velasco M, Filella X, Alvarez L, Làzzari E, MarínLJ, et al. Evaluation of inflammatory and renal injury markers in women treated with antibiotics for acute pyelonephritis caused by escherichia coli. Clin Diagn Lab Immunol 2004; 11(1):142-6.

17. Grażyna K, Agnieszka S, Agnieszka T, Małgorzata PT. Urine interleukin-6, interleukin-8 and transforming growth factor $\beta 1$ in infants with urinary tract infection and asymptomatic bacteriuria. Cent Eur J Immunol 2016;41(3):260-7.

18. Samuel N, Uwaezuoke. Urinary tract infection in children: Diagnostic and prognostic utility of biomarkers. J Compr Ped 2017;8(2):59248.

19. JI-Nan S, Chen MC, Cheng SL, Lee I, Chen SM, Tsay GJ. Urine interleukin-1 $\beta$ in children with acute pyelonephritis and renal scarring. Nephrol 2007;12(5)487-93.

20. Sevketoglu E, Yilmaz A, Gedikbasi A, Karyagar S, Kiyak A, Mulazimoglu $\mathrm{M}$, e $\mathrm{t}$ al. Urinary macrophage migration inhibitory factor in children with urinary tract infection. Pediatr Nephrol 2010;25(2):299.

21. Devillé WL, Yzermans JC, Van Duijn NP, Bezemer PD, Van Der Windt $D A$, Bouter LM. The urine dipstick test useful to rule out infections. A meta-analysis of the accuracy. BMC Urol 2004;4(1)4.

22. Anith KM, Jayalakshmi J, Vinitha L. Rashme, Sanchitha Harini, Sujaya Menon, et al. Reliability of dipstick assayin predicting urinary tract infection. J Family Med Prim Care 2015;4(2):265-8. 